\title{
Geographic distribution of methyltransferases of Helicobacter pylori: evidence of human host population isolation and migration Filipa F Vale ${ }^{1}$, Francis Mégraud ${ }^{2}$ and Jorge MB Vítor*3
}

\author{
Address: ${ }^{1}$ Engineering Faculty, Portuguese Catholic University, Estrada Octávio Pato, 2635-631 Rio de Mouro, Portugal, ${ }^{2}$ INSERM U853, F 33076, \\ Bordeaux, France and ${ }^{3}$ iMed.UL (MedChem Division), Faculty of Pharmacy, University of Lisbon, Av. das Forças Armadas, 1649-003 Lisboa, \\ Portugal \\ Email: Filipa F Vale - filipavale@fe.lisboa.ucp.pt; Francis Mégraud - francis.megraud@chu-bordeaux.fr; Jorge MB Vítor* - jvitor@ff.ul.pt \\ * Corresponding author
}

Published: 8 September 2009

BMC Microbiology 2009, 9:193 doi:10.1/86/147|-2180-9-193
Received: 8 January 2009

Accepted: 8 September 2009

This article is available from: http://www.biomedcentral.com/I47|-2/80/9/193

(C) 2009 Vale et al; licensee BioMed Central Ltd.

This is an Open Access article distributed under the terms of the Creative Commons Attribution License (http://creativecommons.org/licenses/by/2.0), which permits unrestricted use, distribution, and reproduction in any medium, provided the original work is properly cited.

\begin{abstract}
Background: Helicobacter pylori colonizes the human stomach and is associated with gastritis, peptic ulcer, and gastric cancer. This ubiquitous association between $H$. pylori and humans is thought to be present since the origin of modern humans. The $H$. pylori genome encodes for an exceptional number of restriction and modifications (R-M) systems. To evaluate if R-M systems are an adequate tool to determine the geographic distribution of $H$. pylori strains, we typed $22 \mathrm{I}$ strains from Africa, America, Asia, and Europe, and evaluated the expression of different 29 methyltransferases.
\end{abstract}

Results: Independence tests and logistic regression models revealed that ten R-M systems correlate with geographical localization. The distribution pattern of these methyltransferases may have been originated by co-divergence of regional $H$. pylori after its human host migrated out of Africa. The expression of specific methyltransferases in the $H$. pylori population may also reflect the genetic and cultural background of its human host. Methyltransferases common to all strains, $M$. Hhal and M. Nael, are likely conserved in H. pylori, and may have been present in the bacteria genome since the human diaspora out of Africa.

Conclusion: This study indicates that some methyltransferases are useful geomarkers, which allow discrimination of bacterial populations, and that can be added to our tools to investigate human migrations.

\section{Background}

Helicobacter pylori colonizes about half of the human population and is associated with several gastrointestinal diseases, such as gastritis, peptic ulcer, and gastric cancer $[1,2]$. The similar pattern of human and $H$. pylori geographic diversity and distribution suggests a co-evolution between bacteria and man, which can be used to understand human migrations [2]. The H. pylori distribution pattern follows the human migration roots, which sug- gests that the colonization of the human stomach occurred before modern man left East Africa [2-5].

Several $H$. pylori gene alleles present different prevalence rates among the world $H$. pylori population. This is the case for $v a c A$ that presents allelic diversity of the s-, $\mathrm{m}$ - and i-region $[6,7]$. The cagA gene DNA motifs also presents a clear geographic association, and five types of deletion, insertion, and substitution motifs were found at the 3 ' end 
of the H. pylori cag pathogenicity island associated with different human populations [8]. Another study confirms that the candidate virulence factors, vacA, cagA and iceA, cluster according to geographic region [9]. Interestingly, iceA has two known alleles, iceA1 and iceA2 [10,11], with the locus iceA 1 encoding a protein with $52 \%$ identity with the restriction endonuclease NlaIII [12]. Likewise, the $r p o B$ gene, which codes for RNA polymerase $\beta$ subunit, presents allelic diversity between Asian and non-Asian strains at the amino acid threonine, which is present only in Asian strains (two thirds of the Asian strains), while it is substituted with alanine in strains of western origin [13]. Allelic diversity according to the geographic distribution was also found for the $b a b A$ and $b a b B$ genes, which code for outer membrane proteins $[14,15]$.

The transposable element ISHp60 presents a non-random geographic distribution, being more frequent in Latin America and rarer in East Asia [16]. The hopQ (omp27) alleles show high genetic variability, and type I alleles from Western and Asian $H$. pylori strains were similar and markedly different from type II hopQ. Type II hopQ alleles were frequently identified in Western $H$. pylori strains, but rarely in East Asian strains [17].

One class of highly variable genes in the $H$. pylori genome is the restriction and modification (R-M) systems [18]. R$M$ systems usually comprise both a restriction endonuclease (REase) that recognizes a specific DNA sequence and cuts both strands and a cognate DNA methyltransferase (MTase) that methylates the same DNA sequence, thus protecting it from being cleaved by the companion REase [19]. The sequenced $H$. pylori strains, strain 26695 [20], strain J99 [18], strain HPAG1 [21], and strain G27 [22], revealed 26 putative restriction and modification (R-M) systems in the first two strains, and 31 and 34 in the last two [23]. Only a reduced number of the expressed MTases in strains $J 99$ and 26695 are common [24,25]. A small fraction of the potential type II R-M systems in strains $J 99$ and 26695 appear to be fully functional, but different sets of these R-M genes are functionally active in each strain $[26,27]$. The analysis of the expression of MTases in other strains confirmed the high number of expressed enzymes, as well as their diversity among strains [27-31]. Likewise, non-pylori Helicobacter spp. appears to express a high number of MTases, as it was previously determined for $H$. pylori [32]. It has been proposed that the diversity of R-M systems in $H$. pylori is high enough to be used as a typing method [30,31]. Takata et al. studied the genomic methylation status in $122 \mathrm{H}$. pylori strains from several world regions, by performing hydrolysis with 14 REases. This study confirmed the diversity and the high number of expressed MTases, but did not reveal any significant association with the H. pylori geographic origin [29].
The biological function of R-M systems has yet to be ascertained. Typically, R-M systems function like an immune system to protect bacteria against invasion of foreign DNA, especially of bacteriophages [33]. However there is a limited number of reports on $H$. pylori phages [34-36], which also support other biological roles for R-M systems. These may include regulation of genetic exchange in the naturally competent $H$. pylori $[37,38]$ or promotion of homologous recombination between DNA fragments produced by incomplete REase digestion [39]. The linkage of R-M genes allows for simultaneous loss of $\mathrm{R}$ and $\mathrm{M}$ genes, while physical separation of their gene products permits the hydrolysis of the genomic DNA by the residual REase present in daughter cells, leading to postsegregational killing. This occurs because when cells divide, the daughter cells lose the ability to protectively methylate all recognition sites in the newly synthesized chromosome, causing the cleavage of unmethylated sites by the residual REase still present in the bacterial cytoplasm [40,41]. The stability of the expression appears to be rather stable $(94.9 \%)$ in strains isolated from the same patient at different times [30].

In the present study, the majority of strain specific genes with known function, e. g., those that code for restriction and modification (R-M) systems [18], were evaluated for their association with the geographic origin of the $H$. pylori strains. Since $H$. pylori co-evolved with man [2], it is important to understand if these strain specific genes (restriction and modification genes) reflect a similar geographic distribution between man and bacteria characteristic of isolated population. The expression of 29 MTases was assessed by hydrolysis of genomic DNA with the cognate REases in $221 \mathrm{H}$. pylori strains from Africa, America, Asia and Europe. Data were statistically analysed using independence tests as well as multiple and multinomial logistic regression models. Here, we present a geographic pattern for 10 MTases expressed in H. pylori and two conserved MTases expressed in all strains tested. We further explored the association of these MTases with geographic clusters of $H$. pylori populations to determine if the divergence of regional $H$. pylori populations is associated with its human host migrations and genetic/cultural habits.

\section{Results \\ DNA modification in strains from different geographic origin}

The percentage of strains resistant to hydrolysis was determined after clustering the strains by country and continent. The total data set corresponds to 6409 DNA hydrolyses (221 × 29 REases, Additional file 1: Table S1). Analyses were done in duplicate for 250 of these digestions, with similar results (data not shown). All strains presented variable resistance to digestion, as previously described $[18,24,25,27,30,31]$. The resistance to hydroly- 
sis ranged from 100\%, with NaeI and HhaI, to $0 \%$ with Sau3AI (Additional file 2: Table S2 and Figure S1). The number of expressed MTases in $H$. pylori strains was high, as reported $[18,26,27,29,30]$, with a total average of 15.8 \pm 2.2 , (range 9-20), among 27 tested REases (isoschizomers excluded).

\section{Selection of methyltransferases with non-random geographic distribution}

A chi-square independence test was used to select the independent variables to be applied in the logistic regression models (Additional file 2: Table S3). Ten MTases were associated with the geographic origin of the strains analysed. A significant result was determined by the analysis of standardized residuals (std. residual) for all MTases presenting a geographic association, except $\mathrm{M}$. MspI and M. TaqI (Table 1). A Fischer test was applied and all significant associations were confirmed (Additional file 2: Table S4).

\section{Multiple logistic regression}

The 10 MTases with significant association with strain origin (Table 1) were used as independent variables for the multiple logistic regression. A logistic regression was calculated to predict the strain origin (Europe versus nonEurope; or Africa versus non-Africa). Considering that the majority of strains are of European origin, the output variable, or dependent variable, was established as Europe/ non-Europe. The model was statistically significant $(\mathrm{p}=$ $0.00040)$, i.e. the selected independent variables were significant for the output. Four MTases yielded significant results for the logistic regression model: M. AseI, M. FokI, M. MspI, and M. HpyCH4III. M. AseI expression is associated with the European group and the other 3 MTases with the non-European group (Additional file 2: Table S5). When the dependent variable is Africa/non-Africa origin and we use the same 10 independent variables, the full model is once again significant ( $\mathrm{p}=0.0001$ ) (Additional file 2: Table S6). For this model we identified 5 significant MTases: M. AseI, M. MspI, M. Hpy188I, M. Hpy99I, and M. HpyCH4III. There was an association of the expression of M. MspI and M. HpyCH4II with African strains (Odds Ratio, OR>1). The other MTases were associated with the strains of non-African origin $(\mathrm{OR}<1)$.

\section{Multinomial logistic regression}

A multinomial logistic regression presented a nominal outcome variable with 4 levels: Africa, Asia, America, and Europe. When the same 10 MTases (Table 1) were analysed the standard errors were greater than 2 for M. FokI and M. FauI (data not shown), which limited the interpretation of the model. Thus, the multinomial logistic regression was run again with 8 independent variables, although the other two MTases were significant to the full model $(\mathrm{p}<0.05)$.

The multinomial logistic regression model revealed the absence of expression of M. MspI and M. HpyCH4III in the European group with $\mathrm{OR}=4.51$, and $\mathrm{OR}=4.34$, respectively. This strongly suggests that the expression of both MTases were more likely to be present in the African group than in the European group (Additional file 2: Table S7). Regarding the American and African groups, the expression of M. Hpy188I and M. Hpy99I was more likely to occur in the American group than in the African reference group, with $\mathrm{OR}=0.17$ and $\mathrm{OR}=0.16$, respectively. Concerning the Asian group, M. HpyCH4III was more frequent in the African group than in the Asian one, with $\mathrm{OR}=16.98$. M. BstUI was more likely to be present in the Asian group, with $\mathrm{OR}=0.07$. When the reference category corresponded to European isolates, the comparison with the African group yielded similar findings to the ones described previously, but allowed for the comparison between Europe and America, and Europe and Asia.

Table I: MTases presenting a statistical significant association with isolates of distinct geographic origin (Chi-square test).

\begin{tabular}{|c|c|c|c|c|c|}
\hline \multirow[t]{2}{*}{ MTase } & \multirow[t]{2}{*}{ Recognition sequence * } & \multirow{2}{*}{$\begin{array}{l}\text { Chi-square } \\
\text { ( } p \text { value) }\end{array}$} & higher & smaller & \multirow{2}{*}{$\begin{array}{l}\text { Std. } \\
\text { Residua }\end{array}$} \\
\hline & & & \multicolumn{2}{|c|}{ expression in isolates from } & \\
\hline M. Asel & АТТАAT & 0.031 & -- & Africa & 2.13 \\
\hline M. Fokl & GGATG & 0.001 & $\begin{array}{l}\text { America } \\
\text { Asia }\end{array}$ & -- & $\begin{array}{l}2.77 \\
2.55\end{array}$ \\
\hline M. Mspl & CCGG & 0.036 & - & -- & \\
\hline M. Hpyl88I & TCNGA & 0.002 & America & -- & 2.05 \\
\hline М. Нру99I & CGWCG & 0.025 & America & -- & 2.29 \\
\hline M. HpyCH4III & CANGT & $<0.001$ & $\begin{array}{l}\text { Africa } \\
\text { America }\end{array}$ & -- & $\begin{array}{l}-1.99 \\
-2.21\end{array}$ \\
\hline M. Dral & TTTAAA & $<0.001$ & Asia & -- & 5.36 \\
\hline M. BstUI & CGCG & 0.006 & Asia & -- & 2.81 \\
\hline M. Faul & CCCGC & 0.004 & Asia & -- & -2.04 \\
\hline M. Taql & TCGA & 0.044 & -- & -- & \\
\hline
\end{tabular}

* data from REBASE [23]. 
Resistance to restriction by Hpy188I, Hpy99I and HpyCH4III was more likely to be observed in the American group than in the reference group, with OR values of $0.37,0.35$, and 0.19 , respectively. The reference category and the Asian group assessment revealed an $\mathrm{OR}=0.12$ for M. BstUI, and an OR $=0.07$ for M. DraI, which indicated that both MTases were more common among Asian strains (Additional file 2: Table S8).

A summary of the MTase geographic pattern determined by all statistical tests can be found in Table 2 .

\section{Discussion}

The considerable genetic diversity among strains of $H$. pylori [42] has already been used to discriminate between closely related human populations, that could not be discriminated by human genetic markers. H. pylori sequence analysis has the potential to distinguish short term genetic changes in human populations [43].

Most methyltransferases genes are part of restriction and modification systems in $H$. pylori genome $[18,23,44]$. These genes represent about $2 \%$ of the total number of

Table 2: List of MTases with statistically significant association with geographic area of strain isolation.

\begin{tabular}{|c|c|c|}
\hline MTase & Expression* & Absence of expression* \\
\hline M. Asel & $\begin{array}{l}\text { Europe } \\
\text { OR = 2.33; } 95 \% \mathrm{Cl}(\mathrm{I} .00-5.46) \text { a) }\end{array}$ & $\begin{array}{l}\text { Africa } \\
\text { P-value }=0.03083 \text { Std. Residual } 2.13 \mathrm{e}) \\
\left.\mathrm{OR}=0.27 ; 95 \% \mathrm{Cl}(0.10-0.75)^{\mathrm{b}}\right)\end{array}$ \\
\hline M. BstUI & $\begin{array}{l}\text { Asia } \\
\text { P-value = } 0.00639 \text { Std. Residual } 2.8 \mathrm{I}) \\
O R=1 / 0.12=8.33 ; 95 \% \mathrm{Cl}(1.37-50.00) \mathrm{c}) \\
\mathrm{OR}=1 / 0.07=14.29 ; 95 \% \mathrm{Cl}(2.13-100.00) \mathrm{d})\end{array}$ & $\begin{array}{l}\text { Africa } \\
\text { OR }=0.07 ; 95 \% \mathrm{Cl}(0.0 \mathrm{I}-0.47) \text { d) } \\
\text { Europe } \\
\text { OR }=0.12 ; 95 \% \mathrm{Cl}(0.02-0.73) \text { c) }\end{array}$ \\
\hline M. Dral & $\begin{array}{l}\text { Asia } \\
\text { P-value < } 0.0000 \mathrm{I} \text { Std. Residual 5.36e) } \\
\text { OR }=1 / 0.07=14.29 ; 95 \% \mathrm{Cl}(2.63-100.00) \text { c) }\end{array}$ & $\begin{array}{l}\text { Africa } \\
\text { Europe } \\
\mathrm{OR}=0.07 ; 95 \% \mathrm{Cl}(0.0 \mathrm{I}-0.38) \mathrm{c})\end{array}$ \\
\hline M. Faul & $\begin{array}{l}\text { Asia } \\
\text { P-value }=0.00403 \text { Std. Residual }-2.04 \mathrm{e})\end{array}$ & \\
\hline M. Fokl & $\begin{array}{l}\text { America } \\
\text { P-value }=0.00058 \mathrm{Std} . \text { Residual } 2.77 \mathrm{e}) \\
\text { Asia } \\
\text { P-value }=0.00058 \mathrm{Std} . \text { Residual } 2.50 \mathrm{e})\end{array}$ & $\begin{array}{l}\text { Africa } \\
\text { Europe } \\
\mathrm{OR}=0.12 ; 95 \% \mathrm{Cl}(0.02-0.70)^{\text {a) }}\end{array}$ \\
\hline M. Hpy $188 I$ & $\begin{array}{l}\text { America } \\
\mathrm{P} \text {-value = } 0.00177 \text { Std. Residual } 2.05 \mathrm{e}) \\
\mathrm{OR}=1 / 0.17=5.88 ; 95 \% \mathrm{Cl}(\mathrm{I} .89-20.00) \mathrm{d}) \\
\left.\mathrm{OR}=1 / 0.37=2.70 ; 95 \% \mathrm{Cl}(1.09-6.67)^{\mathrm{c}}\right) \\
\text { Asia }\end{array}$ & $\begin{array}{l}\text { Africa } \\
\text { OR }=0.35 ; 95 \% \mathrm{Cl}(0.14-0.87) \mathrm{b}) \\
\mathrm{OR}=0.17 ; 95 \% \mathrm{Cl}(0.05-0.53) \mathrm{d}) \\
\text { Europe } \\
\text { OR }=0.37 ; 95 \% \mathrm{Cl}(0.15-0.92) c)\end{array}$ \\
\hline М. Нpy99l & $\begin{array}{l}\text { America } \\
\text { P-value }=0.02544 \text { Std. Residual 2.29e) } \\
\text { OR }=1 / 0.16=6.25 ; 95 \% \mathrm{Cl}(1.79-20.00) \mathrm{d}) \\
\left.\mathrm{OR}=1 / 0.35=2.86 ; 95 \% \mathrm{Cl}(1.14-7.14)^{c}\right)\end{array}$ & $\begin{array}{l}\text { Africa } \\
\mathrm{OR}=0.35 ; 95 \% \mathrm{Cl}(0.12-0.99) \mathrm{b}) \\
\mathrm{OR}=0.16 ; 95 \% \mathrm{Cl}(0.05-0.56) \mathrm{d}) \\
\text { Europe } \\
\text { OR }=0.35 ; 95 \% \mathrm{Cl}(0.14-0.88) \text { c) }\end{array}$ \\
\hline M. HpyCH4III & $\begin{array}{l}\text { America } \\
\text { P-value }=0.000 I 5 \text { Std. Residual }-2.21 \text { e) } \\
\text { OR }=1 / 0.19=5.26 ; 95 \% \mathrm{Cl}(\mathrm{I} .15-25.00) \mathrm{c}) \\
\text { Africa } \\
\mathrm{P} \text {-value }=0.000 \mathrm{I} 5 \mathrm{Std} \text {. Residual }-\mathrm{I} .99 \mathrm{e}) \\
\mathrm{OR}=4.44 ; 95 \% \mathrm{Cl}(\mathrm{I} .46-13.47) \mathrm{b}) \\
\mathrm{OR}=1 / 0.23=4.35 ; 95 \% \mathrm{Cl}(\mathrm{I} .47-12.50) \mathrm{c}) \\
\mathrm{OR}=4.34 ; 95 \% \mathrm{Cl}(\mathrm{I} .46-12.87) \mathrm{d}) \\
\mathrm{OR}=16.98 ; 95 \% \mathrm{Cl}(2.33-123.98) \mathrm{d})\end{array}$ & $\begin{array}{l}\text { Asia } \\
\text { OR }=1 / / 6.98=0.06 ; 95 \% \mathrm{Cl}(0.0 \mathrm{I}-0.43) \text { d) } \\
\text { Europe } \\
\text { OR }=0.4 \mathrm{I} ; 95 \% \mathrm{Cl}(0.20-0.88) \text { a) } \\
\text { OR }=1 / 4.34=0.23 ; 95 \% \mathrm{Cl}(0.08-0.68) \text { d) } \\
\text { OR }=0.23 ; 95 \% \mathrm{Cl}(0.08-0.68) \text { c) } \\
\text { OR }=0.19 ; 95 \% \mathrm{Cl}(0.04-0.87) \text { c) }\end{array}$ \\
\hline M. Mspl & $\begin{array}{l}\text { Africa } \\
\text { P-value }=0.03638 \mathrm{e}) \\
\mathrm{OR}=4.42 ; 95 \% \mathrm{Cl}(\mathrm{I} .46-\mathrm{I} .43) \mathrm{b}) \\
\mathrm{OR}=1 / 0.22=4.55 ; 95 \% \mathrm{Cl}(\mathrm{I} .49-\mathrm{I}(4.29) \mathrm{c}) \\
\mathrm{OR}=4.5 \mathrm{I} ; 95 \% \mathrm{Cl}(\mathrm{I} .49-\mathrm{I} .67) \mathrm{d})\end{array}$ & $\begin{array}{l}\text { Europe } \\
\text { OR }=0.45 ; 95 \% \mathrm{Cl}(0.22-0.94) \text { a) } \\
O R=1 / 4.5 \mathrm{I}=0.22 ; 95 \% \mathrm{Cl}(0.07-0.67) \mathrm{d}) \\
\mathrm{OR}=0.22 ; 95 \% \mathrm{Cl}(0.07-0.67) \mathrm{c})\end{array}$ \\
\hline
\end{tabular}

\footnotetext{
* Statistical analysis information:
}

a) Multiple logistic regression: dependent variable Europe or non-Europe;

b) Multiple logistic regression: dependent variable Africa or non-Africa;

c) Multinomial regression: reference category Europe;

d) Multinomial regression: reference category Africa;

e) Chi-square independence test ( $\mathrm{p}$-value and std. residual);

Note: in multinomial regression Odds Ratio (OR) values are determined for the absence of expression. The introduction of the inverse value allows the indication of OR value for presence of expression of each MTase. A OR 95\% confidence interval is presented. 
genes $[18,20,21]$, a very high proportion when compared with the mean percentage of methyltransferase $(M)$ genes per sequenced genome in Bacteria (0.50\%) [23]. The average number of R-M genes present in $H$. pylori sequenced genomes is 30 , an extremely high value considering all sequenced bacterial genomes, with an average of $4.3 \mathrm{R}-\mathrm{M}$ systems per genome [23]. In addition to the high number of R-M systems present in $\mathrm{H}$. pylori genome, which represent more than half of the strain-specific genes [45,46], these R-M systems also present a high diversity among strains $[18,24,25,27-29,47]$, allowing them to be used as a typing system [30,31]. Moreover, some R-M systems are more prevalent in $H$. pylori than others, resulting in rare, medium, and frequent R-M systems [29,30,48]. The present study confirms the high number of $\mathrm{M}$ genes expressed per $H$. pylori strain, independently of its geographic origin and suggests that MTase expression is clearly associated with strain origin. To date, there is only one study [29] specifically designed to characterize MTases expression from different geographic origins. This report confirmed the diversity and the high number of expressed MTases, but did not reveal any significant MTase association with the geographic origin of $H$. pylori [29]. The difficulty in finding an association with geographic origin, may be due to the low number of strains analysed (122 strains),, which included only 3 strains from Africa as well as the limited number of MTases tested (14 REases). Table 2 summarizes MTases that present statistically significant geographic association. The odds ratio may present small differences for the same MTase, given analysis by several logistic regression models. Regardless, the values are always significant for an association between MTase and strain origin.

Table 3: Genomes with higher number of predicted $M$ genes [23].
Our results suggest that the pattern of some $H$. pylori MTases is geographically defined, which may indicate that it is the result of geographic isolation of its human host or of the co-divergence of $H$. pylori MTases with host since the migration of modern human out of Africa. R-M systems present a lower $\mathrm{G}+\mathrm{C}$ content than the total genome (Table 3), which has been considered as evidence for horizontal gene transfer [49-51]. Frequently, genes coding for $\mathrm{R}-\mathrm{M}$ systems are within or adjacent to insertions with long target duplications, which suggests a similar transposon insertion with longer duplications, in agreement with an horizontal gene transfer [52]. Horizontal gene transfer of $H$. pylori MTases could favour the geographic isolation hypothesis. However, if we consider that phase variation does not seem to appear in R-M systems [53], and that temporal analysis of gene expression appears to be rather stable [30], MTases are likely not that mobile among genomes. Even though R-M systems may be mainly acquired by horizontal gene transfer, the fact that their expression appears to be stable after acquisition [30,53], arguing for a post segregational killing effect $[41,54,55]$, and that $H$. pylori transmission occurs mainly within the same nuclear family or community [56-58], supports the concept of conservation of some R-M systems since the diaspora out of Africa [59], and the acquisition of other R$M$ genes later on, in specific geographic areas. Finally, the existence of MTases common to all geographic groups, $\mathrm{M}$. NaeI and M. HhaI, is consistent with the hypothesis of $H$. pylori and Homo sapiens co-evolution after the human outof-Africa movement $[2,3]$. It is assumed that modern humans appeared first in Africa, then in Asia, and from this continent they settled in three neighbouring regions: Oceania, Europe and America [4]. All H. pylori strains express the MTases M. HhaI and M. NaeI, suggesting that

\begin{tabular}{|c|c|c|c|c|c|c|}
\hline Organism & Genome size (Mbp) & Total genes & $M$ genes & $\%$ M Genes a) & \% GC Genome b) & \% GC RM genes c) \\
\hline Microcystis aeruginosa NIES-843 & 5.84 & 6312 & 51 & 0.81 & 42 & 40 \\
\hline Microcystis aeruginosa PCC 7806 & $?$ & $?$ & 42 & $?$ & 42 & 40 \\
\hline Roseiflexus sp. RS-I & 5.80 & 4517 & 38 & 0.83 & 60 & 58 \\
\hline $\begin{array}{l}\text { Roseiflexus castenholzii DSM } \\
\text { |394| }\end{array}$ & 5.72 & 4330 & 36 & 0.83 & 60 & 56 \\
\hline $\begin{array}{l}\text { Campylobacter upsaliensis } \\
\text { RM3195 }\end{array}$ & 1.77 & 1998 & 34 & 1.70 & 34 & 34 \\
\hline Helicobacter pylori G27 & 1.65 & 1493 & 34 & 2.28 & 38 & 37 \\
\hline Helicobacter pylori HPAGI & 1.60 & 1536 & 32 & 2.08 & 39 & 37 \\
\hline Helicobacter pylori Shi470 & 1.61 & 1569 & 32 & 2.04 & 38 & 36 \\
\hline Orientia tsutsugamushi Boryong & 2.13 & 1182 & 31 & 2.62 & 30 & 28 \\
\hline Helicobacter acinonychis Sheeba & 1.55 & 1612 & 29 & 1.80 & 38 & 35 \\
\hline Helicobacter pylori $\mathrm{PI} 2$ & 1.67 & 1567 & 29 & 1.85 & 38 & 36 \\
\hline Cenarchaeum symbiosum & 2.05 & 2017 & 28 & 1.39 & 57 & 52 \\
\hline Helicobacter pylori 26695 & 1.67 & 1576 & 28 & 1.78 & 39 & 36 \\
\hline Helicobacter pylori $j 99$ & 1.64 & 1489 & 28 & 1.88 & 39 & 36 \\
\hline
\end{tabular}

a) percentage of $M$ genes ( $M$ genes/total genes)

b) percentage of $G C$ content in the sequenced genome

c) mean percentage of GC content among R-M system genes present within the genome 
they have been present in the genome since the beginning of human dispersion from the Africa continent. Moreover, $M$. HhaI is an isoschizomer of $M$. Hpy99III, $M$. HpyORF1059P and M. HpyAVIII, which are MTases identified in $H$. pylori strains J99 (coded by hpy99IIIM), HPAG1 (coded by hpyHORF1059MP), 26695 (coded by hpyAVIIIM), and Shi470 (coded by HPSH_05770), respectively $[23,60]$. The identification of $\mathrm{M}$. HhaI isoschizomers in three sequenced strains is in agreement with the hypothesis of these MTases being present in the H. pylori genome since the beginning of the human migrations.

It has been proposed that genes coding for R-M system were acquired recently, by horizontal gene transfer, with new systems being constantly acquired while old ones are inactivated or eliminated [27]. Our results support the hypothesis that at least some R-M systems were acquired since human migration out of Africa, while others were obtained later by geographically isolated bacterial populations. It is likely that the first MTases to be stably acquired by $H$. pylori genome were $\mathrm{M}$. HhaI and M. NaeI, while the others were added later (Figure 1).

The other MTases showing a significant geographic association have probably been acquired at a later stage, depending on the H. pylori geographic localization. Thus, African strains are associated with M. HpyCH4III and M. MspI; Asian strains with M. BstUI, M. DraI, M. FauI, M.
FokI and M. Hpy188I; European strains with M. AseI; and, finally, American strains with M. HpyCH4III, M. Hpy99I, M. Hpy188I e M. FokI (Figure 1).

Some MTases are common to more than one continent of origin, as is the case for M. FokI and M. Hpy188I, being both associated with Asia and America. Human migrations from Asia to America could provide some clues to this observation. The presence of both MTases supports the hypothesis of $H$. pylori and man co-evolution since the settlement of modern man (and H. pylori) in Asia, and posterior settlement in American land between 10,000 and 25,000 years ago, when a land bridge (the Bering Strait) connected Siberia and Alaska during the last ice age [4]. The expression of M. HpyCH4III in African and American strains, but not in the Asian ones, suggests that this MTase was acquired later and that the corresponding strains gained access to America in a second wave of migration of African slaves [4]. It should be pointed out that most of the American strains analysed are from South and Central American countries, which also experienced human traffic of African origin, although to a smaller extent when compared with other countries, such as Brazil. FokI's resistance to cleavage, which in the present study associated with Asian and American strains, has been previously reported for American and Asian strains, but not European and African [29], which is in agreement with the present study. Likewise, M. Hpy99I and M.

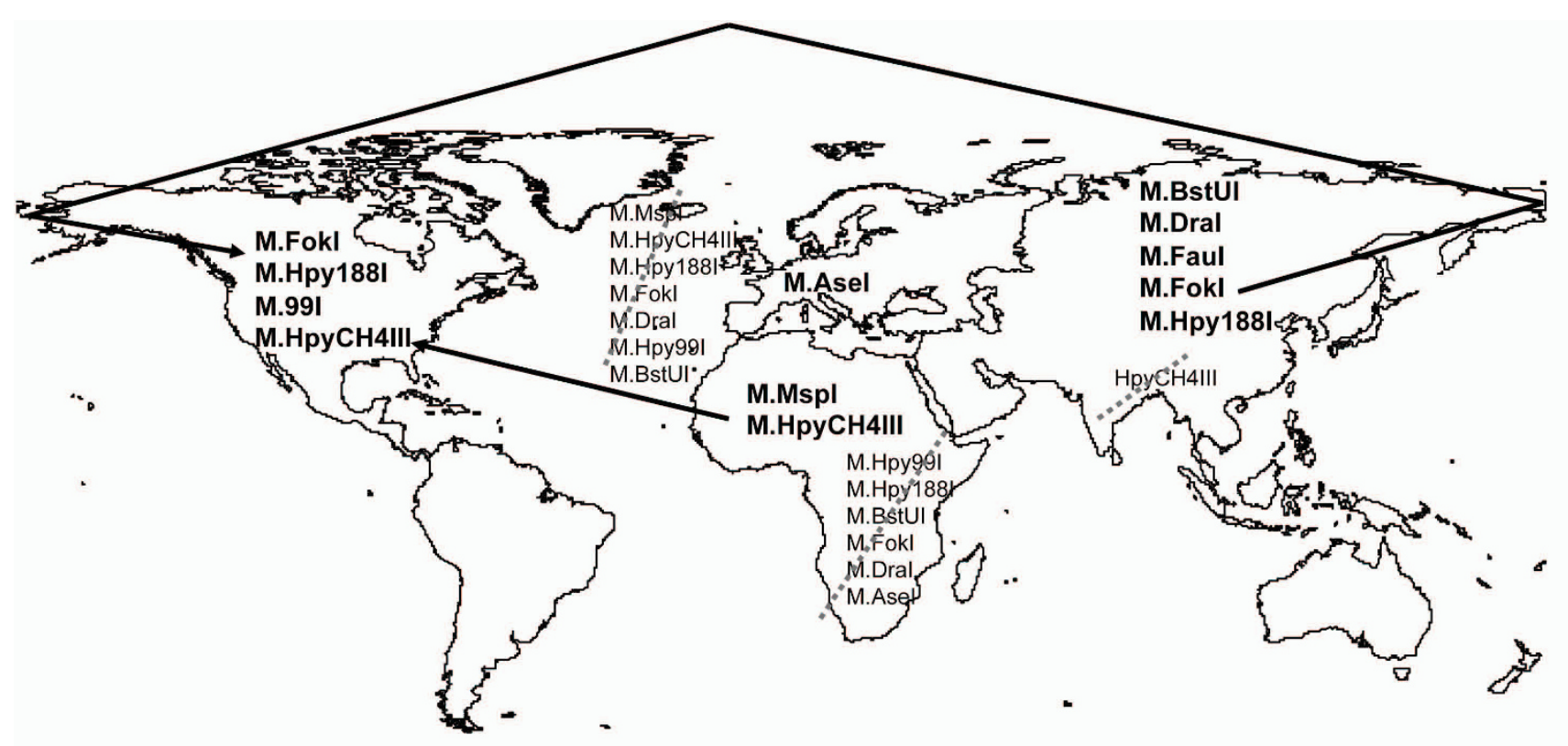

Figure I

Geographic distribution of $\boldsymbol{H}$. pylori genomic methylation. MTases with specific geographic origin are in bold. Arrows indicate MTases that are associated with a strain from more than a continent, according to human migrations predicted by Cavalli-Sforza. Grey dashed lines indicate MTases, whose absence is significantly associated with continent of strain origin. 
Hpy188I associated with the American strains and were first isolated from the strains J99 and J188, also of American origin $[18,61]$. Only M. HpyCH4III, which is associated with American strains and not with Asian strains in the present study, was first isolated from a Chinese strain [31]. However, only strains from Singapore where considered in the Asian group, which is a limitation of this study. Nine out of ten of the Singapore strains (strains id. 33, 3537, 39, 40, 42-43, available at Helicobacter pylori MLST Databases [62]) were common with the study of Falush et al. After the sequence of eight genes (including vacA, which presents allelic diversity) the majority of these strains were assigned to the hspEastAsia subpopulation [5]. This is in accordance with present results, since both studies clearly isolate these strains. For European, American and African strains, the dimension and diversity of these subgroups is higher, yielding more robust results.

It is thought that intra-familiar transmission plays a more important role in urban families than in rural families, where the horizontal transmission (for instance via nonparental caretakers) is predominant [63]. H. pylori appears to have established a long lasting colonization of its human host [64], probably being transmitted to subsequent human hosts by close human contact, e.g. between family or community members $[63,65]$, depending on the genetic and social-cultural habits of each population. Our study supports previous reports on the co-evolution of $H$. pylori and man, in the sense that $H$. pylori reflects human migrations [3], being transmitted among individuals who have close contact with each other, but are not necessarily family members.

The biologic role of R-M systems is not completely understood. It remains an enigma if the increased number of MTases present in the $H$. pylori genome provides selective advantage to the bacteria, or if it is simply the result of the natural competence and postsegregational killing effects. Methylation has implications in gene expression [66], and $H$. pylori associates with several pathologies that may result from different sets of expressed genes [67]. For instance, DNA methylation by M. HpyAIV was shown to alter transcription of the catalase gene (katA) in H. pylori [68]. Further evidence is needed to understand if the high number and diversity of MTases expressed among $H$. pylori strains is beneficial for the bacteria and/or plays any role in pathogenicity.

\section{Conclusion}

In conclusion, there is a clear association of some MTases with geographic groups of $H$. pylori strains, making them useful as geomarkers (Table 2). Indeed, other genes, as cagA or $v a c A$, have allelic forms with particular geographic distributions $[6,8,69]$. Similar results are now observed for the majority strain-specific genes. M. HhaI and $M$.
NaeI are common to all tested strains, which is consistent with the co-evolution theory of man and $H$. pylori $[2,3]$ and suggests that their presence in bacterial genome preceded the human diaspora out of Africa. Finally, the association of MTases with geographical bacterial clusters may be observed in other bacterial species, and may reveal to be good geographic markers to trace bacterial evolution.

\section{Methods \\ H. pylori strains}

$221 \mathrm{H}$. pylori strains were isolated from different regions (Africa, America, Asia and Europe) (Table 4). Strains belong to the collections of the Helicobacter and Campylobacter Reference Center of the Portuguese National Institute of Health (INSA), the Helicobacter and Campylobacter National Reference Center (Victor Segalen University, Bordeaux, France) and the Medical Microbiology Institute of Hannover (Germany). Strains belonging to INSA and Helicobacter and Campylobacter National Reference Center were randomly selected, except in cases in which all strains available for each sub-sample group were analysed (strains with African origin). DNA from $H$. pylori Singapore strains was randomly selected from East Asia H. pylori strain collection of the Medical Microbiology Institute of Hannover. Except for the country of origin, there is no further information about the ethnic group or ancestry of the human host providing the strain. Due to difficulty in obtaining strains from different geographic origins the number of strains from each continent is uneven.

\section{H. pylori culture and genomic DNA extraction}

H. pylori culture and DNA extraction were performed as previously described $[30,70]$.

\section{Determination of MTase expression}

Genomic DNA from each strain was hydrolysed with 29 REases: AciI, AseI, BseRI, BssHII, BssKI, BstUI, DdeI, DpnI, DpnII, DraI, EagI, FauI, Fnu4HI, FokI, HaeIII, HhaI, HpaII, Hpy188I, Hpy99I, HpyCH4III, HpyCH4IV, HpyCH4V, MspI, NaeI, NlaIII, Sau3AI, Sau96I, ScrFI and TaqI. Digestions were performed according to the manufacturer (New England Biolabs, USA), in a reaction volume of $50 \mu \mathrm{l}$. A negative control, without REase, was performed for a set of reactions. The results were coded on a binary matrix, where " 0 " indicates digestion observed (DNA is unmethylated), and " 1 " indicates no digestion, suggesting an active methyltransferase [30].

\section{Statistical analysis}

For each MTase, a significance level of 0.05 was considered for the chi-square test, using the SPSS v.15.0. The chisquare test allowed to select MTases with an association with the origin of the isolates that were later used in logistic regression models. A Fischer test was performed to select MTases when the chi-square test was not valid (cells 
Table 4: Geographic origin of $H$. pylori strains.

\begin{tabular}{|c|c|c|c|}
\hline Continent & Country & Number of strains & Percentage \\
\hline \multirow[t]{7}{*}{ Europe } & & 146 & 66.1 \\
\hline & Portugal & 106 & 48.0 \\
\hline & France & 11 & 5.0 \\
\hline & United Kingdom a) & 8 & 3.6 \\
\hline & Germany & 6 & 2.7 \\
\hline & Sweden & 9 & 4.1 \\
\hline & Norway & 6 & 2.7 \\
\hline \multirow[t]{4}{*}{ Africa } & & 38 & 17.2 \\
\hline & Portuguese with African origin b) & 20 & 9.0 \\
\hline & Egypt & 7 & 3.2 \\
\hline & Burkina Faso & 11 & 5.0 \\
\hline \multirow[t]{5}{*}{ America } & & 27 & 12.2 \\
\hline & USA c) & 1 & 0.5 \\
\hline & Costa Rica & 6 & 2.7 \\
\hline & Mexico & 6 & 2.7 \\
\hline & Argentina & 14 & 6.3 \\
\hline \multirow[t]{2}{*}{ Asia } & & 10 & 4.5 \\
\hline & Singapore & 10 & 4.5 \\
\hline Total & & 221 & 100.0 \\
\hline
\end{tabular}

a) Includes sequenced strain 26695 ;

b) Strains isolated from African patients with Portuguese residence were considered African;

c) Includes sequenced strain $\mathbf{j 9 9}$.

with expected counts lower than 5). The selected MTases were the independent variables (IV) in the logistic regression models. Multiple logistic regression used selected MTases as IV and a binary (dichotomous) dependent variable (DV) [71,72]. We chose Africa and non-Africa strains as DV, since it is accepted that $H$. pylori co-evolved with man since the human diaspora out of Africa [2-4]. Considering that the majority of strains were from European origin, another model was run, with European and nonEuropean strains as DV. IV was also dichotomic (expression and no expression of MTase). The logistic regression allows for determination of the most adequate, parsimonious and biologically reasonable model describing the relation between the answer (or dependent variable) and the independent (or predictive) variable. Multinomial logistic regression models were also determined to analyze potential relationships between a non-metric dependent variable (four geographic origins) and metric or dichotomous independent variables and to compare multiple groups through a combination of binary logistic regressions [72]. The reference strain group was the African group, in agreement with the hypothesis of co-evolution of $H$. pylori and man [2,3] or the European group, since it consisted in a larger sub-sample.

\section{Authors' contributions}

FV designed and performed research, analyzed data and prepared the manuscript. FM provided strain collection and contributed to the manuscript. JV designed research and contributed to the manuscript. All authors approved the final manuscript

\section{Additional material}

\section{Additional file 1}

Vale et al. - Geographic distribution of methyltransferases of Helicobacter pylori: evidence of human host population isolation and migration - Global data matrix. additional table presenting global results.

Click here for file

[http://www.biomedcentral.com/content/supplementary/1471-

2180-9-193-S1.xls]

\section{Additional file 2}

Vale et al. - Geographic distribution of methyltransferases of Helicobacter pylori: evidence of human host population isolation and migration - Additional file of statistical analysis. additional tables and figure presenting statistical analysis data.

Click here for file

[http://www.biomedcentral.com/content/supplementary/1471-

2180-9-193-S2.doc]

\section{Acknowledgements}

We thank Lurdes Monteiro and Sebastian Suerbaum for the H. pylori strains, Patrícia Fonseca and Rui Moreira for critical review of the manuscript, and Afonso Cavaco, António Belo and Dinis Pestana for helping on the logistic regression analysis. This work was partially supported by New England Biolabs, Inc. (USA).

\section{References}

I. Suerbaum S, Michetti P: Helicobacter pylori infection. N Engl J Med 2002, 347: II75-II86.

2. Covacci A, Telford JL, Del GG, Parsonnet J, Rappuoli R: Helicobacter pylori virulence and genetic geography. Science 1999, 284: 1328-1333. 
3. Linz B, Balloux F, Moodley Y, Manica A, Liu H, Roumagnac P, Falush D, Stamer C, Prugnolle F, Merwe SW van der, Yamaoka Y, Graham DY, Perez-Trallero E, Wadstrom T, Suerbaum S, Achtman M: An African origin for the intimate association between humans and Helicobacter pylori. Nature 2007, 445:915-918.

4. Cavalli-Sforza LL: Genes, Peoples and Languages London: Penguin Books; 200I.

5. Falush D, Wirth T, Linz B, Pritchard JK, Stephens M, Kidd M, Blaser MJ, Graham DY, Vacher S, Perez-Perez GI, Yamaoka Y, Megraud F, Otto K, Reichard U, Katzowitsch E, Wang X, Achtman M, Suerbaum S: Traces of human migrations in Helicobacter pylori populations. Science 2003, 299: I 582-I585.

6. Van Doorn LJ, Figueiredo C, Sanna R, Pena S, Midolo P, Ng EK, Atherton JC, Blaser MJ, Quint WG: Expanding allelic diversity of Helicobacter pylori vacA. J Clin Microbiol 1998, 36:2597-2603.

7. Rhead JL, Letley DP, Mohammadi M, Hussein N, Mohagheghi MA, Eshagh HM, Atherton JC: A new Helicobacter pylori vacuolating cytotoxin determinant, the intermediate region, is associated with gastric cancer. Gastroenterology 2007, I 33:926-936.

8. Kersulyte D, Mukhopadhyay AK, Velapatino B, Su W, Pan Z, Garcia C, Hernandez V, Valdez Y, Mistry RS, Gilman RH, Yuan Y, Gao H, Alarcon T, Lopez-Brea M, Balakrish NG, Chowdhury A, Datta S, Shirai M, Nakazawa T, Ally R, Segal I, Wong BC, Lam SK, Olfat FO, Boren T, Engstrand L, Torres O, Schneider R, Thomas JE, Czinn S, Berg DE: Differences in genotypes of Helicobacter pylori from different human populations. J Bacteriol 2000, I 82:32 I0-32 I8.

9. Li L, Graham DY, Gutierrez O, Kim JG, Genta RM, El-Zimaity HM, Go MF: Genomic fingerprinting and genotyping of Helicobacter pylori strains from patients with duodenal ulcer or gastric cancer from different geographic regions. Dig Dis Sci 2002, 47:2512-25I8.

10. Donahue JP, Peek RM, Van Doorn LJ, Thompson SA, Xu Q, Blaser MJ, Miller GG: Analysis of iceAl transcription in Helicobacter pylori. Helicobacter 2000, 5: $1-12$

II. Xu Q, Blaser MJ: Promoters of the CATG-specific methyltransferase gene hpyIM differ between iceAI and iceA2 Helicobacter pylori strains. J Bacteriol 200I, I 83:3875-3884.

12. Figueiredo C, Quint WG, Sanna R, Sablon E, Donahue JP, Xu Q, Miller GG, Peek RM Jr, Blaser MJ, Van Doorn L): Genetic organization and heterogeneity of the iceA locus of Helicobacter pylori. Gene 2000, 246:59-68.

13. Lee KH, Cho MJ, Yamaoka Y, Graham DY, Yun YJ, Woo SY, Lim CY, Ko KS, Kim BJ, Jung HC, Lee WK, Rhee KH, Kook YH: Alaninethreonine polymorphism of Helicobacter pylori RpoB is correlated with differential induction of interleukin-8 in MKN45 cells. J Clin Microbiol 2004, 42:3518-3524.

14. Pride DT, Blaser MJ: Concerted evolution between duplicated genetic elements in Helicobacter pylori. J Mol Biol 2002, 3 1 6:629-642.

15. Pride DT, Meinersmann RJ, Blaser MJ: Allelic Variation within Helicobacter pylori babA and babB. Infect Immun 200I, 69:1|60-II7|.

16. Kersulyte D, Velapatino B, Dailide G, Mukhopadhyay AK, Ito Y, Cahuayme L, Parkinson AJ, Gilman RH, Berg DE: Transposable element ISHp608 of Helicobacter pylori: nonrandom geographic distribution, functional organization, and insertion specificity. J Bacteriol 2002, I 84:992-1002.

17. Cao P, Lee KJ, Blaser MJ, Cover TL: Analysis of hopQ alleles in East Asian and Western strains of Helicobacter pylori. FEMS Microbiol Lett 2005, 25 1:37-43.

18. Alm RA, Ling LS, Moir DT, King BL, Brown ED, Doig PC, Smith DR, Noonan B, Guild BC, dejonge BL, Carmel G, Tummino PJ, Caruso A, Uria-Nickelsen M, Mills DM, Ives C, Gibson R, Merberg D, Mills SD, jiang Q, Taylor DE, Vovis GF, Trust TJ: Genomic-sequence comparison of two unrelated isolates of the human gastric pathogen Helicobacter pylori. Nature 1999, 397:176-180.

19. Roberts RJ, Belfort M, Bestor T, Bhagwat AS, Bickle TA, Bitinaite J, Blumenthal RM, Degtyarev SK, Dryden DT, Dybvig K, Firman K, Gromova ES, Gumport RI, Halford SE, Hattman S, Heitman J, Hornby DP, Janulaitis A, Jeltsch A, Josephsen J, Kiss A, Klaenhammer TR, Kobayashi I, Kong H, Kruger DH, Lacks S, Marinus MG, Miyahara M, Morgan RD, Murray NE, Nagaraja V, Piekarowicz A, Pingoud A, Raleigh E, Rao DN, Reich N, Repin VE, Selker EU, Shaw PC, Stein DC, Stoddard BL, Szybalski W, Trautner TA, Van Etten JL, Vitor JM, Wilson GG, Xu SY: A nomenclature for restriction enzymes, DNA methyl- transferases, homing endonucleases and their genes. Nucleic Acids Res 2003, 31:1805-1812.

20. Tomb JF, White O, Kerlavage AR, Clayton RA, Sutton GG, Fleischmann RD, Ketchum KA, Klenk HP, Gill S, Dougherty BA, Nelson K, Quackenbush J, Zhou L, Kirkness EF, Peterson S, Loftus B, Richardson D, Dodson R, Khalak HG, Glodek A, McKenney K, Fitzegerald LM, Lee N, Adams MD, Hickey EK, Berg DE, Gocayne JD, Utterback TR, Peterson JD, Kelley JM, Cotton MD, Weidman JM, Fujii C, Bowman C, Watthey L, Wallin E, Hayes WS, Borodovsky M, Karp PD, Smith HO, Fraser CM, Venter JC: The complete genome sequence of the gastric pathogen Helicobacter pylori. Nature 1997, 388:539-547.

21. Oh JD, Kling-Backhed H, Giannakis $M, X u$ J, Fulton RS, Fulton LA, Cordum HS, Wang C, Elliott G, Edwards J, Mardis ER, Engstrand LG, Gordon Jl: The complete genome sequence of a chronic atrophic gastritis Helicobacter pylori strain: evolution during disease progression. Proc Natl Acad Sci USA 2006, 1 03:9999-10004.

22. Baltrus DA, Amieva MR, Covacci A, Lowe TM, Merrell DS, Ottemann KM, Stein M, Salama NR, Guillemin K: The Complete Genome Sequence of Helicobacter pylori strain G27. J Bacteriol 2009 , 191:447-448.

23. Roberts RJ, Vincze T, Posfai J, Macelis D: REBASE - enzymes and genes for DNA restriction and modification. Nucleic Acids Res 2007, 35:D269-D270.

24. Vitkute J, Stankevicius K, Tamulaitiene G, Maneliene Z, Timinskas A, Berg DE, Janulaitis A: Specificities of eleven different DNA methyltransferases of Helicobacter pylori strain 26695. J Bacteriol 200I, I 83:443-450.

25. Nobusato A, Uchiyama I, Kobayashi I: Diversity of restrictionmodification gene homologues in Helicobacter pylori. Gene 2000, 259:89-98.

26. Kong H, Lin LF, Porter N, Stickel S, Byrd D, Posfai J, Roberts RJ: Functional analysis of putative restriction-modification system genes in the Helicobacter pylori $\mathbf{J 9 9}$ genome. Nucleic Acids Res 2000, 28:3216-3223.

27. Lin LF, Posfai J, Roberts RJ, Kong $\mathrm{H}$ : Comparative genomics of the restriction-modification systems in Helicobacter pylori. Proc Natl Acad Sci USA 2001, 98:2740-2745.

28. Aras RA, Small AJ, Ando T, Blaser MJ: Helicobacter pylori interstrain restriction-modification diversity prevents genome subversion by chromosomal DNA from competing strains. Nucleic Acids Res 2002, 30:5391-5397.

29. Takata T, Aras R, Tavakoli D, Ando T, Olivares AZ, Blaser MJ: Phenotypic and genotypic variation in methylases involved in type II restriction-modification systems in Helicobacter pylori. Nucleic Acids Res 2002, 30:2444-2452.

30. Vale FF, Vitor JM: Genomic Methylation: a Tool for Typing Helicobacter pylori Isolates. Appl Environ Microbiol 2007, 73:4243-4249.

31. Xu Q, Morgan RD, Roberts RJ, Blaser MJ: Identification of type II restriction and modification systems in Helicobacter pylori reveals their substantial diversity among strains. Proc Natl Acad Sci USA 2000, 97:9671-9676.

32. Vale FF, Vítor JMB: Genomic methylation status for discrimination among Helicobacter species: a bioinformatics approach. J Proteomics Bioinformatics 2008, I:258-266.

33. Arber W: Host-controlled modification of bacteriophage. Annu Rev Microbiol 1965, 19:365-378.

34. Heintschel von HE, Nalik HP, Schmid EN: Characterisation of a Helicobacter pylori phage (HPI). I Med Microbiol 1993, 38:245-249.

35. Schmid EN, von RG, Ansorg R: Bacteriophages in Helicobacter (Campylobacter) pylori. J Med Microbiol 1990, 32:10I-I04.

36. Vale FF, Alves Matos AP, Carvalho P, Vitor JM: Helicobacter pylori phage screening. Microsc Microanal 2008, I 4(supp 3): |50-|5|.

37. Hofreuter D, Odenbreit S, Puls J, Schwan D, Haas R: Genetic competence in Helicobacter pylori: mechanisms and biological implications. Res Microbiol 2000, I 5 I:487-49 I.

38. Israel DA, Lou AS, Blaser MJ: Characteristics of Helicobacter pylori natural transformation. FEMS Microbiol Lett 2000 , I 86:275-280.

39. Kobayashi I: Homologous recombination and sex as a strategy against selfish genes attacking the genome. Ann N Y Acad Sci 1999, 870:354-356. 
40. Kusano K, Naito T, Handa N, Kobayashi I: Restriction-modification systems as genomic parasites in competition for specific sequences. Proc Natl Acad Sci USA 1995, 92: I I095-I I 099.

4I. Naito T, Kusano K, Kobayashi I: Selfish behavior of restrictionmodification systems. Science 1995, 267:897-899.

42. Bjorkholm B, Sjolund M, Falk PG, Berg OG, Engstrand L, Andersson DI: Mutation frequency and biological cost of antibiotic resistance in. Helicobacter pylori 200I, 98: |4607-I46I2.

43. Wirth T, Wang X, Linz B, Novick RP, Lum JK, Blaser M, Morelli G, Falush $D$, Achtman $M$ : Distinguishing human ethnic groups by means of sequences from Helicobacter pylori: lessons from Ladakh. Proc Natl Acad Sci USA 2004, I 0 I:4746-475I.

44. Takahashi N, Naito $Y$, Handa N, Kobayashi I: A DNA methyltransferase can protect the genome from postdisturbance attack by a restriction-modification gene complex. J Bacteriol 2002, | 84:6100-6108.

45. Alm RA, Trust TJ: Analysis of the genetic diversity of Helicobacter pylori: the tale of two genomes. I Mol Med 1999, 77:834-846

46. Salama N, Guillemin K, McDaniel TK, Sherlock G, Tompkins L, Falkow $S$ : A whole-genome microarray reveals genetic diversity among Helicobacter pylori strains. Proc Natl Acad Sci USA 2000, 97: | 4668-14673.

47. Lehours P, Dupouy S, Chaineux J, Ruskone-Fourmestraux A, Delchier JC, Morgner A, Megraud F, Menard A: Genetic diversity of the HpyCII restriction modification system in Helicobacter pylori. Res Microbiol 2007, I 58:265-27I.

48. Humbert O, Salama NR: The Helicobacter pylori HpyAXII restriction-modification system limits exogenous DNA uptake by targeting GTAC sites but shows asymmetric conservation of the DNA methyltransferase and restriction endonuclease components. Nucleic Acids Res 2008.

49. Kobayashi I, Nobusato A, Kobayashi-Takahashi N, Uchiyama I: Shaping the genome - restriction-modification systems as mobile genetic elements. Curr Opin Genet Dev 1999, 9:649-656.

50. Kobayashi I: Behavior of restriction-modification systems as selfish mobile elements and their impact on genome evolution. Nucleic Acids Res 2001, 29:3742-3756.

51. Kobayashi I: Restriction-Modification systems as minimal forms of life. In Restriction endonucleases Edited by: Pingoud A. Berlin: Springer-Verlag; 2004:19-62.

52. Nobusato A, Uchiyama I, Ohashi S, Kobayashi I: Insertion with long target duplication: a mechanism for gene mobility suggested from comparison of two related bacterial genomes. Gene 2000, 259:99-108.

53. Salaun L, Ayraud S, Saunders NJ: Phase variation mediated niche adaptation during prolonged experimental murine infection with Helicobacter pylori. Microbiology 2005, I 5 I:917-923.

54. Kobayashi I: Selfishness and death: raison d'etre of restriction, recombination and mitochondria. Trends Genet 1998 , 14:368-374

55. Handa N, Kobayashi I: Post-segregational killing by restriction modification gene complexes: observations of individual cell deaths. Biochimie 1999, 81:931-938.

56. Bamford KB, Bickley J, Collins JS, Johnston BT, Potts S, Boston V, Owen RJ, Sloan JM: Helicobacter pylori: comparison of DNA fingerprints provides evidence for intrafamilial infection. Gut 1993, 34:1348-1350.

57. Kivi M, Tindberg Y, Sorberg M, Casswall TH, Befrits R, Hellstrom PM Bengtsson C, Engstrand L, Granstrom M: Concordance of Helicobacter pylori strains within families. J Clin Microbiol 2003, 4l:5604-5608

58. Raymond J, Thiberg JM, Chevalier C, Kalach N, Bergeret M, Labigne A, Dauga C: Genetic and transmission analysis of Helicobacter pylori strains within a family. Emerg Infect Dis 2004, I 0:1816-1821.

59. Vale FF, Encarnacao P, Vitor JM: A new algorithm for cluster analysis of genomic methylation: the Helicobacter pylori case. Bioinformatics 2008, 24:383-388.

60. Altschul SF, Madden TL, Schaffer AA, Zhang J, Zhang Z, Miller W, Lipman DJ: Gapped BLAST and PSI-BLAST: a new generation of protein database search programs. Nucleic Acids Res 1997, 25:3389-3402

6I. Xu Q, Stickel S, Roberts RJ, Blaser MJ, Morgan RD: Purification of the novel endonuclease, Hpy 1881 , and cloning of its restriction-modification genes reveal evidence of its horizontal transfer to the Helicobacter pylori genome. J Biol Chem 2000 , 275: I7086-I7093.

62. Jolley KA, Chan MS, Maiden MC: mlstdbNet - distributed multilocus sequence typing (MLST) databases. BMC Bioinformatics 2004, 5:86.

63. Schwarz S, Morelli G, Kusecek B, Manica A, Balloux F, Owen RJ, Graham DY, van der MS, Achtman M, Suerbaum S: Horizontal versus familial transmission of Helicobacter pylori. PLoS Pathog 2008, 4:e1000180.

64. Lundin A, Bjorkholm B, Kupershmidt I, Unemo M, Nilsson P, Andersson DI, Engstrand L: Slow genetic divergence of Helicobacter pylori strains during long-term colonization. Infect Immun 2005, 73:48I8-4822.

65. Raymond J, Thiberge JM, Kalach N, Bergeret M, Dupont C, Labigne A, Dauga C: Using macro-arrays to study routes of infection of Helicobacter pylori in three families. PLOS ONE 2008, 3:e2259.

66. Casadesus J, Low D: Epigenetic gene regulation in the bacterial world. Microbiol Mol Biol Rev 2006, 70:830-856.

67. Atherton JC: $\boldsymbol{H}$. pylori virulence factors. Br Med Bull 1998, 54: $105-120$

68. Skoglund A, Bjorkholm B, Nilsson C, Andersson AF, Jernberg C, Schirwitz K, Enroth C, Krabbe M, Engstrand L: Functional analysis of the M. HpyAIV DNA methyltransferase of Helicobacter pylori. J Bacteriol 2007, I 89:89|4-892I.

69. Wong BC, Yin Y, Berg DE, Xia HH, Zhang JZ, Wang WH, Wong WM, Huang $X R$, Tang VS, Lam SK: Distribution of distinct vacA, cagA and iceA alleles in Helicobacter pylori in Hong Kong. Helicobacter 2001, 6:317-324.

70. Megraud F: Diagnostic bactériologique standart de l'infection à Helicobacter pylori. In Helicobacter pylori Edited by: Megraud F, Lamouliatte H. Amsterdam: Elsevier; 1996:249-266.

7I. Maroco J: Análise estatística com utilização do SPSS 3rd edition. Lisboa: Edições Sílabo; 2007.

72. Hosmer DW, Lemeshow S: Applied logistic regression 2nd edition. New York: Wiley-Interscience Publication; 2000.
Publish with Biomed Central and every scientist can read your work free of charge

"BioMed Central will be the most significant development for disseminating the results of biomedical research in our lifetime. "

Sir Paul Nurse, Cancer Research UK

Your research papers will be:

- available free of charge to the entire biomedical community

- peer reviewed and published immediately upon acceptance

- cited in PubMed and archived on PubMed Central

- yours - you keep the copyright
BioMedcentral 